\title{
In vitro fertilization and embryo development in pigs
}

\author{
L. R. Abeydeera
}

\author{
PIC International, 2929 Seventh Street, Suite 130, Berkeley, CA 94710, USA
}

Considerable progress has been made in the in vitro production of pig embryos using improved methods for in vitro maturation (IVM) and fertilization (IVF). Despite the progress, polyspermic penetration remains a problem for in vitro-matured oocytes. Variation among boars, ejaculates and IVF protocols used in different laboratories appears to influence the incidence of polyspermy. Recent studies indicate that oviduct cells and their secretions play a role in reducing polyspermy. Very early attempts to culture in vivo-derived pig embryos met with little success and most were arrested at the four-cell stage. At present, many culture media are available that can overcome the four-cell block and support development to the blastocyst stage. In contrast, blastocyst development of in vitro-produced (IVP) embryos in these culture media varies significantly. Significant differences in morphology and numbers of cells have been observed in in vitro-produced blastocysts compared with in vivo-derived blastocysts. Surgical transfer of in vitro-produced embryos to recipient animals has resuited in acceptable pregnancy rates with moderate litter sizes. Although several systems are available for the generation of in vitro-produced embryos, the problems of polyspermy and poor embryo survival prevent large-scale production of embryos. Further research should be directed to improve oocyte and embryo quality, and to develop methods to minimize polyspermy through development of better IVM, IVF and embryo culture techniques.

\section{Introduction}

Owing to their physiological similarities to humans, pigs are increasingly important in biomedical research. Interest has grown in the use of transgenic pigs to produce specific proteins and as potential xenograft donors. Attempts to produce transgenic pigs by pronuclear microinjection require early embryos. Surgical collection of early embryos from donor animals is time-consuming, expensive and offers limited numbers of embryos. Therefore, it is important to produce large numbers of developmentally competent embryos by in vitro techniques for biomedical and basic research purposes.

Numerous reports describe maturation and fertilization of pig oocytes under in vitro conditions. Initially, nuclear maturation was achieved but problems with poor male pronuclear formation and high incidence of polyspermic penetration were observed routinely after in vitro fertilization (IVF) (Niwa, 1993; Funahashi and Day, 1997; Day et al., 2000a). Oocyte maturation processes can be divided broadly into two aspects, namely nuclear and 
Table 1. Sperm penetration obtained under various IVF conditions

\begin{tabular}{|c|c|c|c|c|c|}
\hline $\begin{array}{l}\text { IVF medium and } \\
\text { supplements }\end{array}$ & $\begin{array}{c}\text { Type of } \\
\text { spermatozoa }\end{array}$ & $\begin{array}{c}\text { Sperm } \\
\text { concentration } \\
\left(\times 10^{6} \mathrm{ml}^{-1}\right)\end{array}$ & $\begin{array}{l}\text { Type of } \\
\text { oocyte }\end{array}$ & $\begin{array}{l}\text { Penetration } \\
\text { rate }(\%)\end{array}$ & Reference \\
\hline TCM $+10 \%$ FCS +2 mmol caffeine $\mathrm{l}^{-1}$ & Fresh & 2 & $\begin{array}{l}\text { In vivo (follicular) } \\
\text { In vivo (ovulated) }\end{array}$ & $\begin{array}{c}80-100^{\mathrm{a}} \\
100^{\mathrm{a}}\end{array}$ & Yoshida, 1987 \\
\hline $\mathrm{BO}+0.1 \% \mathrm{BSA}+2 \mathrm{mmol}$ caffeine $\mathrm{l}^{-1}$ & Frozen-thawed (epididymal) & 24 & $\begin{array}{l}\text { IVM } \\
\text { In vivo (ovulated) }\end{array}$ & $\begin{array}{l}42^{\mathrm{a}} \\
79^{\mathrm{b}}\end{array}$ & Nagai et al., 1988 \\
\hline $\mathrm{TCM}+10 \% \mathrm{FCS}+5 \mathrm{mmol}$ caffeine $\mathrm{l}^{-1}$ & Frozen-thawed (ejaculated) & $\begin{array}{c}1 \\
6 \\
12 \\
25 \\
50\end{array}$ & IVM & $\begin{array}{c}0 \\
12 \\
43 \\
88 \\
85\end{array}$ & Wang et al., 1991 \\
\hline $\begin{array}{l}\mathrm{TCM}+10 \% \mathrm{FCS}+5 \mathrm{mmol} \text { caffeine } \mathrm{l}^{-1} \\
\mathrm{TCM}+0.4 \% \mathrm{BSA}+5 \mathrm{mmol} \text { caffeine } \mathrm{l}^{-1}\end{array}$ & $\begin{array}{l}\text { Fresh } \\
\text { Fresh }\end{array}$ & $\begin{array}{r}1 \\
1\end{array}$ & $\begin{array}{l}\text { IVM } \\
\text { IVM }\end{array}$ & $\begin{array}{l}94^{\mathrm{a}} \\
85^{\mathrm{a}}\end{array}$ & Funahashi and Day, 1993 \\
\hline 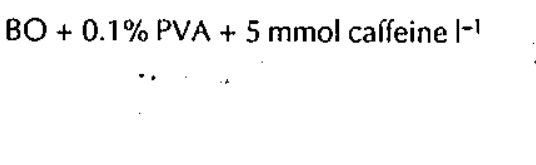 & Frozen-thawed (ejaculated) & $\begin{array}{rl} & 4-5 \\
& 7-8 \\
1 & 10-12\end{array}$ & IVM & $\begin{array}{l}28^{\mathrm{a}} \\
45^{\mathrm{b}} \\
44^{\mathrm{b}}\end{array}$ & Wang et al., 1995 \\
\hline $\begin{array}{l}\mathrm{mTBM}+0.1 \% \mathrm{BSA} \\
\mathrm{mTBM}+0.1 \% \mathrm{BSA}+1 \mathrm{mmol} \text { caffeine } \mathrm{l}^{-1}\end{array}$ & $\begin{array}{l}\text { Frozen-thawed (ejaculated) } \\
\text { Frozen-thawed (ejaculated) }\end{array}$ & $\begin{array}{l}1 \\
1\end{array}$ & $\begin{array}{l}\text { IVM } \\
\text { IVM }\end{array}$ & $\begin{array}{l}48^{\mathrm{a}} \\
96^{\mathrm{b}}\end{array}$ & Abeydeera and Day, 1997a \\
\hline TALP $+0.6 \%$ BSA & $\begin{array}{l}\text { Fresh } \\
\text { Frozen-thawed (ejaculated) }\end{array}$ & $\begin{array}{l}1 \\
1\end{array}$ & $\begin{array}{l}\text { IVM } \\
\text { IVM }\end{array}$ & $\begin{array}{l}71-100^{a} \\
56-94^{a}\end{array}$ & Cordova et al., 1997 \\
\hline
\end{tabular}

TCM: tissue culture medium; FCS: fetal calí serum; BO: Brackett and Oliphant medium; PVA: polyvinylalcohol; mTBM: modified Tris-buffered medium; TALP: Tyrode's albumin lactate pyruvate medium; IVM: in vitro-malured.

abWithin a study, different superscripts indicate significant differences $(P \leqslant 0.05)$. 
cytoplasmic maturation. Although nuclear maturation appears to be normal, the degree of cytoplasmic maturation under those initial maturation conditions is unknown.

After many years of research, various modifications to the in vitro maturation (IVM) system have alleviated the problem of male pronuclear formation. However, polyspermy remains a major unresolved problem. It has not been established whether this abnormality is due to inadequate conditions during IVM, IVF or both. Despite the problem of polyspermy, successful production of pig embryos via in vitro techniques has improved markedly. Furthermore, transfer of embryos to recipient animals has resulted in acceptable pregnancy rates and litter sizes. This review will discuss recent progress in IVF and embryo culture techniques in pigs. It is envisaged that the development of new or optimization of existing in vitro techniques will result in further advances in embryo technology.

\section{In vitro fertilization}

\section{Factors affecting sperm penetration}

Fertilization medium and source of spermatozoa. Various types of fertilization medium, in conjunction with fresh or frozen-thawed spermatozoa at different concentrations, have been used to achieve in vitro penetration of pig oocytes (Table 1). Freshly ejaculated semen is still the main source of spermatozoa for routine IVF studies. Nevertheless, large variations among boars, as well as among different fractions within the same ejaculate, are observed in oocyte penetration and polyspermy (Xu et al., 1996a,b). These authors found that the use of a specific sperm-rich fraction of the ejaculate can reduce the variability among different ejaculates collected from the same boar. Cryopreservation of semen from a single ejaculate would allow the optimization of IVF protocols and minimize the variability between trials. However, the same IVF protocol may not provide optimal conditions for frozen semen from other boars. It is necessary to optimize the IVF protocol for each individual batch of frozen semen to realise desirable IVF parameters because of variation in the ability of spermatozoa from different boars to withstand cryopreservation.

Bicarbonate concentration. Most IVF media contain $\mathrm{NaHCO}_{3}$ concentrations that maintain a desirable $\mathrm{pH}$ under specific culture conditions. In vivo, spermatozoa undergo a process called capacitation before they are capable of penetrating an oocyte. Once ejaculated, spermatozoa are confronted with higher bicarbonate concentrations within the female tract, perhaps indicating a role for this ion (Harrison, 1996). In the presence of bicarbonate, a considerable number of sperm proteins become tyrosine-phosphorylated during in vitro capacitation (Flesch and Gadella, 2000). Bicarbonate concentration in IVF medium can influence the sperm penetration of pig oocytes (Table 2). Assessment of the functional status by chlortetracycline fluorescent staining indicated that $\mathrm{HCO}_{3}$ - stimulated capacitation and acrosome reaction of spermatozoa in a concentration- and time-dependent manner (Abeydeera et al., 1997). Suzuki et al. (1994a) showed that $\mathrm{HCO}_{3}{ }^{-}$was essential during IVF of pig oocytes under these conditions. However, successful sperm penetration in a Tris-buffered medium (Abeydeera and Day, 1997a,b) is evidence against the universal requirement for bicarbonate during pig IVF.

Calcium concentration. Extracellular $\mathrm{Ca}^{2+}$ is required for sperm capacitation and the ability to undergo an acrosome reaction (Flesch and Gadella, 2000). Current evidence indicates that calcium plays a critical role in modulating sperm function and is obligatory for successful fertilization in mammals (Fraser, 1995). Indeed, calcium is necessary during IVF of pig 
Table 2. Sperm penetration of pig oocytes in the presence of bicarbonate

\begin{tabular}{lccc}
\hline IVF condition & $\begin{array}{c}\text { Bicarbonate } \\
\left(\mathrm{mmol} \mathrm{I}^{-1}\right)\end{array}$ & $\begin{array}{c}\text { Penetration } \\
\text { rate }(\%)\end{array}$ & Reference \\
\hline mBO + 0.1\% PVA + 5 mmol caffeine $\left.\right|^{-1}$ & 37 & $37^{\mathrm{a}}$ & Wang et al., 1995 \\
& 41 & $51^{\mathrm{a}}$ & \\
$\mathrm{TCM}+10 \%$ FCS + 5 mmol caffeine $\mathrm{I}^{-\mathrm{I}}$ & 45 & $76^{\mathrm{b}}$ & \\
& 50 & $74^{\mathrm{b}}$ & \\
& 26 & $63^{\mathrm{a}}$ & Abeydeera et al., 1997 \\
& 36 & $88^{\mathrm{b}}$ & \\
\hline
\end{tabular}

mBO: modified Brackett and Oliphant medium; PVA: polyvinylalcohol; FCS: fetal calf serum; TCM: tissue culture medium. abWithin a study, different superscripts indicate significant differences $(P<0.05)$.

Table 3. Effect of various types of macromolecule on fertilization parameters in pigs

\begin{tabular}{lcc}
\hline Type of supplement & Penetration rate $(\%)$ & Polyspermy (\%) \\
\hline None & $14^{\mathrm{a}}$ & 5 \\
PVA $\left(5 \mathrm{mg} \mathrm{ml}^{-1}\right)$ & $19^{\mathrm{ab}}$ & 15 \\
PVP $\left(5 \mathrm{mg} \mathrm{ml}^{-1}\right)$ & $27^{\mathrm{b}}$ & 8 \\
FCS $(10 \%)$ & $57^{\mathrm{c}}$ & 79 \\
BSA $\left(5 \mathrm{mg} \mathrm{m}^{-1}\right)$ & $77^{\mathrm{d}}$ & 82 \\
\hline
\end{tabular}

Data from Suzuki et al. (1994b).

PVA: polyvinylalcohol; PVP: polyvinylpyrrolidone; FCS: fetal calf serum.

abcdDifferent superscripts indicate significant differences among values $(P \leqslant 0.05)$.

oocytes, as Abeydeera and Day (1997a) showed that penetration did not occur in its absence and that penetration rate increased with increasing concentrations of calcium.

Macromolecular supplements. Most pig IVF media are supplemented with fetal calf serum (FCS; Yoshida, 1987; Wang et al., 1991) or BSA (Nagai et al., 1988; Abeydeera and Day, 1997a) as a protein source but some studies have used polyvinylalcohol (PVA; Wang et al., 1995) or polyvinylpyrrolidone (PVP; Suzuki et al., 1994b) under defined conditions. Using modified Tyrode's medium containing $4.6 \mathrm{mmol} \mathrm{CaCl}_{2} \mathrm{I}^{-1}$ and $2 \mathrm{mmol}$ caffeine $\mathrm{I}^{-1}$, Suzuki et al. (1994b) showed that the type of macromolecule added during IVF has a significant influence on sperm penetration (Table 3 ). In addition, the amount of BSA or FCS added to IVF medium could also influence the fertilization rate.

Caffeine. Most pig IVF media are supplemented with caffeine, a phosphodiesterase inhibitor, which could increase CAMP within sperm cells, leading to capacitation (Flesch and Gadella, 2000). In a previous study, Wang et al. (1991) failed to obtain sperm penetration in the absence of caffeine and higher penetration rates were obtained at 2.5-10.0 mmol caffeine $\left.\right|^{-1}$ followed by a decrease at $20 \mathrm{mmol}$ caffeine $\left.\right|^{-1}$ (Table 4). Nagai et al. (1994) obtained a similar pattern but failed to obtain penetration with $2 \mathrm{mmol}$ caffeine $\mathrm{I}^{-1}$. In contrast, recent 
Table 4. Sperm penetration of pig oocytes in the presence of caffeine

\begin{tabular}{|c|c|c|c|c|}
\hline IVF condition & Source of spermatozoa & $\begin{array}{c}\text { Caffeine } \\
\left(\text { mmol }\left.\right|^{-1}\right)\end{array}$ & $\begin{array}{l}\text { Penetration } \\
\text { rate }(\%)\end{array}$ & Reference \\
\hline $\mathrm{TCM}+\mathrm{FCS}$ & $\begin{array}{l}\text { Frozen-thawed } \\
\text { (ejaculated) }\end{array}$ & $\begin{array}{l}0 \\
2.5 \\
5 \\
20\end{array}$ & $\begin{array}{r}0^{\mathrm{a}} \\
70^{\mathrm{b}} \\
89^{\mathrm{c}} \\
9^{\mathrm{a}}\end{array}$ & Wang et al., 1991 \\
\hline $\mathrm{BO}+\mathrm{BSA}$ & $\begin{array}{l}\text { Frozen-thawed } \\
\text { (epididymal) }\end{array}$ & $\begin{array}{r}0 \\
2 \\
5 \\
15 \\
20\end{array}$ & $\begin{array}{r}0^{\mathrm{a}} \\
0^{\mathrm{a}} \\
45^{\mathrm{b}} \\
59^{\mathrm{b}} \\
32^{\mathrm{c}}\end{array}$ & Nagai et al., 1994 \\
\hline $\mathrm{mTBM}+\mathrm{BSA}$ & $\begin{array}{l}\text { Frozen-thawed } \\
\text { (ejaculated) }\end{array}$ & $\begin{array}{l}0 \\
1 \\
5\end{array}$ & $\begin{array}{l}48^{\mathrm{a}} \\
96^{\mathrm{b}} \\
95^{\mathrm{b}}\end{array}$ & Abeydeera and Day, 1997a \\
\hline $\mathrm{mBO}+\mathrm{BSA}$ & $\begin{array}{l}\text { Frozen-thawed } \\
\text { (ejaculated) }\end{array}$ & $\begin{array}{l}0 \\
1\end{array}$ & $\begin{array}{l}50^{a} \\
98^{b}\end{array}$ & Funahashi et al., 2000 \\
\hline
\end{tabular}

TCM: tissue culture medium; FCS: fetal calf serum; mBO: modified Brackett and Oliphant medium; mTBM: modified Tris-buffered medium.

abcWithin a study, different superscripts indicate significant differences $(P \leqslant 0.05)$.

studies have shown penetration in about $50 \%$ of oocytes without caffeine (Abeydeera and Day, 1997a; Funahashi et al., 2000). However, penetration rate was increased when caffeine was added during IVF. The disparity among these studies can be attributed to different IVF media or the type of spermatozoa used.

Preincubation of spermatozoa. Preincubation of spermatozoa at various concentrations (Nagai et al., 1984) and the presence of pig follicular fluid during preincubation (Funahashi and Day, 1993) both influence fertilization parameters. Preincubation in the absence of pig follicular fluid stimulates sperm capacitation and results in higher penetration rate and polyspermy. In the presence of pig follicular fluid, capacitation and spontaneous acrosome reaction are stimulated in a concentration-dependent fashion. Such conditions effectively reduce the proportion of capacitated spermatozioa but maintain a high penetration rate with a low incidence of polyspermy. However, high concentrations ( $10 \%$ ) of pig follicular fluid tend to reduce penetration by inducing a higher rate of spontaneous acrosome reaction (Funahashi and Day, 1993).

Sperm concentration and co-incubation interval. Penetration rate and polyspermy are also influenced by sperm concentration and duration of co-incubation with oocytes (Abeydeera and Day, 1997b). More spermatozoa are undergoing capacitation at higher sperm concentrations and may be responsible for the higher penetration rate. However, coincubation of oocytes at a constant sperm concentration for a longer period allows sufficient sperm-oocyte interactions to result in a high incidence of sperm penetration. After reaching the highest penetration rate, a further increase in sperm concentration or co-incubation time tends to increase the incidence of polyspermic penetration. 


\section{Male pronuclear formation}

Much research has been directed towards increasing the male pronuclear formation in pig oocytes after sperm penetration. Various modifications to IVM, such as supplementation of follicular fluid, co-culture with extroverted follicles, limited exposure to gonadotrophins or low $\mathrm{NaCl}$ concentration in culture medium have been used to improve the ability of oocytes to stimulate male pronuclear formation (see Day et al., 2000a). A significant improvement in male pronuclear formation was obtained after supplementation of maturation media with cysteine or glutathione (Yoshida et al., 1992). A later study showed that improvement in male pronuclear formation due to cysteine supplementation is correlated with higher concentrations of intracellular glutathione in matured oocytes (Yoshida et al., 1993). Synthesis of glutathione during oocyte maturation is a prerequisite for sperm nuclear chromatin decondensation and successful male pronuclear formation (Perreault et al., 1988). It appears that male pronuclear formation is compromised in oocytes with lower concentrations of intracellular glutathione.

\section{Polyspermy}

Despite the significant improvements in male pronuclear formation, polyspermy remains a major unresolved problem with IVF of pig oocytes. Under in vivo conditions, fertilization occurs within a few hours after ovulation and in most instances monospermic penetration ensues. Evidence from laboratory and farm animals indicates that the sperm: egg ratio at the time of initial penetration of the egg membranes is close to unity and this ratio increases only after the establishment of a zona block (Hunter, 1993). Under most IVF conditions, oocytes are always exposed to excessive numbers of spermatozoa, which may be a predisposing factor for multiple sperm penetrations. An ideal IVF system should result in a high penetration rate $(>80 \%)$ with a low incidence of polyspermy $(<10 \%)$. A tight correlation has been established between the absolute number of spermatozoa per oocyte at fertilization and the degree of polyspermy (Rath, 1992). Theoretically, the problem of polyspermy could be overcome by reducing the number of spermatozoa within the IVF droplets. However, in most cases, such adjustments are associated with a low oocyte penetration rate.

In mammals, sperm penetration triggers oocyte activation and subsequent cortical granule exocytosis leading to modification of the zona pellucida and block to polyspermy. Cortical granule density within the cytoplasm and exocytosis of these granules after sperm penetration in vitro appears to be similar between in vitro-matured and ovulated pig oocytes (Wang et al., 1998). However, the incidence of polyspermy is higher in in vitro-matured oocytes. The limited perivitelline space in in vitro-matured oocytes may interfere with the proper dispersal of cortical granule contents and delay the establishment of the zona block. it is possible that under IVF conditions, accessory spermatozoa gain entry before establishment of a functional zona block. Pig oocytes matured in Whitten's medium containing a low $\mathrm{NaCl}$ concentration resulted in oocytes with a wider perivitelline space that were less polyspermic (Funahashi et al., 1994a). Therefore, use of an IVM medium that results in matured oocytes with a wider perivitelline space may, at least in part, resolve the problem of polyspermy.

The in vivo counterparts of in vitro-matured oocytes are the mature oocytes from preovulatory follicles. Day et al. (2000b) examined the morphological, physical and fertilization parameters of in vitro-matured, ovulated and preovulatory oocytes (Table 5). For the properties evaluated, in vitro-matured oocytes are similar in quality to preovulatory oocytes. It is clear that after ovulation, major changes to the oocyte take place within the oviduct, which may be important in preventing polyspermy. Compared with controls, surgical transfer of in vitro-matured oocytes to an oestrous oviduct for $4 \mathrm{~h}$ resulted in similar 
Table 5. Morphological, physical and fertilization parameters of ovulated, preovulatory and in vitro-matured pig oocytes

\begin{tabular}{lccc}
\hline & \multicolumn{3}{c}{ Oocyte category } \\
\cline { 2 - 4 } Parameter & IVM & Preovulatory & Ovulated \\
\hline Diameter $(\mu \mathrm{m})$ & $152^{\mathrm{a}}$ & $157^{\mathrm{a}}$ & $165^{\mathrm{b}}$ \\
Zona thickness $(\mu \mathrm{m})$ & $16^{\mathrm{a}}$ & $16^{\mathrm{a}}$ & $18^{\mathrm{b}}$ \\
Size of PVS $(\mu \mathrm{m})$ & $2.6^{\mathrm{a}}$ & $2.6^{\mathrm{a}}$ & $9.4^{\mathrm{b}}$ \\
Zona digestion time $(\mathrm{min})$ & $3-6^{\mathrm{a}}$ & $3-6^{\mathrm{a}}$ & $>60^{\mathrm{b}}$ \\
Penetration rate $(\%)$ & 85 & 82 & 93 \\
Polyspermy $(\%)$ & $64^{\mathrm{a}}$ & $86^{\mathrm{b}}$ & $28^{\mathrm{c}}$ \\
\hline
\end{tabular}

Data from Abeydeera et al. (1999).

PVS: perivitelline space.

abcDifferent superscripts within a row indicate significant differences $(P \leq 0.05)$.

morphological and physical changes as observed in ovulated oocytes. Furthermore, oocytes exposed to the oviduct showed similar penetration rates ( 87 versus $83 \%$ ) but a lower rate of polyspermy (26 versus $67 \%$ ). Many in vitro studies have indicated the beneficial effects of oviduct cells and conditioned media in reducing polyspermy (Table 6). In these studies, oviductal cells were obtained from either prepubertal gilts or animals showing signs of oestrus. Vatzias and Hagen (1999) showed that supplementation of IVF medium with conditioned medium derived from periovulatory oviduct explant culture reduced the incidence of polyspermy compared with conditioned medium from mid-luteal phase oviduct explants and the control group. These results indicate strongly that oviductal secretions contain factors that interact with oocytes or spermatozoa to prevent or reduce entry of multiple spermatozoa.

The oviduct synthesizes and secretes multiple proteins in response to ovarian hormones, thereby creating a microenvironment capable of supporting the events of fertilization and embryo development. A variety of proteins synthesized and secreted by the pig oviduct have been identified (Buhi et al., 2000). Most abundant is the oestrogen-dependent glycoprotein identified as pig oviduct-specific secretory glycoprotein (pOSP). Some other major synthesized proteins include protease inhibitors (tissue inhibitor of metalloproteinase 1 (TIMP-1), plasminogen activator inhibitor I), clusterin, growth factors and cytokines (Buhi et al., 2000). The presence of pOSP in the zona pellucida and perivitelline space of oviductal oocytes and embryos indicates that it may have a physiological role during sperm-oocyte interaction (Buhi et al.; 1993). Exposure of oocytes to semi-purified pOSP $\left(10 \mu \mathrm{g} \mathrm{m}^{-1}\right)$ before and during fertilization significantly reduced the incidence of polyspermy ( 29 versus $61 \%$ ) without compromising sperm penetration ( 63 versus $74 \%$; Kouba et al., 2000). There was no evidence of zona hardening but a reduction in sperm binding to zona pellucida was observed in the presence of pOSP. A different oviductal secretory product may be responsible for the zona hardening observed in ovulated oocytes. However, it is not clear whether the reduction of polyspermy by POSP is due to its interaction with the oocyte or spermatozoa, as oocytes are exposed to the protein before and during fertilization. According to Suzuki et al. (2000), sperm preincubation or sperm-oocyte co-incubation in the presence of hyaluronic acid can reduce polyspermy. Hyaluronic acid has been localized in the tissues and intraluminal fluid of pig oviduct (Tienthai et al., 2001), which indicates that it may be involved during in vivo fertilization. In addition to oviduct glycoproteins, hyaluronic acid may also play a role in modulation of sperm penetration and polyspermy. 
Table 6. Effect of pig oocyte or sperm exposure to oviduct cells or conditioned media before or during IVF on sperm penetration and polyspermy

\begin{tabular}{|c|c|c|c|c|}
\hline Pre-fertilization conditions & Fertilization condition & $\begin{array}{l}\text { Penetration } \\
\text { rate }(\%)\end{array}$ & $\begin{array}{l}\text { Polyspermy } \\
(\%)\end{array}$ & Reference \\
\hline $\begin{array}{l}\text { Preincubation of IVM } \\
\text { oocytes with POEC }\end{array}$ & $\begin{array}{l}\text { IVF with (+) or without (-) } \\
\text { POEC }\end{array}$ & & & Romar et al., 2000 \\
\hline $\mathrm{Oh}$ & + & 61 & $50^{\mathrm{ab}}$ & \\
\hline $\mathrm{Oh}$ & - & 77 & $57 b$ & $\because$ \\
\hline $2 \mathrm{~h}$ & + & 59 & $41^{a}$ & \\
\hline $4 \mathrm{~h}$ & + & 66 & $24^{a}$ & \\
\hline $\begin{array}{l}3 \mathrm{~h} \text { preincubation of IVM } \\
\text { oocytes before IVF in }\end{array}$ & . & & & Bureau et al., 2000 \\
\hline Medium only & & 90 & $45^{a}$ & \\
\hline $\begin{array}{l}\text { Medium conditioned } \\
\text { with POEC for } 24 \mathrm{~h}\end{array}$ & & 87 & $25^{b}$ & \\
\hline $\begin{array}{l}\text { Medium with POEC } \\
\text { added just before } 3 \mathrm{~h} \\
\text { preincubation }\end{array}$ & & 93 & $37^{\mathrm{a}}$ & \\
\hline \multirow[t]{4}{*}{ None } & $\begin{array}{l}\text { Fertilization medium } \\
\text { only (FM) }\end{array}$ & 95 & $93^{\mathrm{a}}$ & Kano et al., 1994 \\
\hline & $\begin{array}{l}\mathrm{FM}+\text { oviduct cell } \\
\text { monolayer }\end{array}$ & 85 & $64^{b}$ & \\
\hline & FM only & 97 & $90^{\circ}$ & \\
\hline & $\begin{array}{l}\text { FM + oviduct } \\
\text { conditioned medium }\end{array}$ & 90 & $73^{b}$ & \\
\hline $\begin{array}{l}\text { Co-culture of spermatozoa } \\
\text { with oviductal cells }\end{array}$ & $\begin{array}{l}\text { Presence of oviduct cells } \\
\text { during IVF }\end{array}$ & & & $\begin{array}{l}\text { Nagai and Moor, } \\
1990\end{array}$ \\
\hline $\mathrm{Oh}$ & - & $89^{a}$ & $81^{\mathrm{a}}$ & \\
\hline $0 \mathrm{~h}$ & + & $89^{\mathrm{a}}$ & $85^{\mathrm{a}}$ & \\
\hline $1.0 \mathrm{~h}$ & + & $94^{a}$ & $71^{\mathrm{ab}}$ & \\
\hline $2.5 \mathrm{~h}$ & + & $84^{a}$ & $53^{b}$ & \\
\hline $3.5 \mathrm{~h}$ & + & $19^{\mathrm{b}}$ & $14^{\mathrm{c}}$ & \\
\hline
\end{tabular}

IVM oocytes: in vitro-matured oocytes; POEC: pig oviduct epithelial cells.

abcWithin a study, different superscripts indicate significant differences $(P \leqslant 0.05)$.

Most pig IVF media are supplemented with caffeine, a phosphodiesterase inhibitor known to increase intracellular CAMP. A recent study, using frozen-thawed ejaculated semen, indicated that when IVF medium (modified Brackett and Oliphant medium; $\mathrm{mBO}$ ) contained caffeine $\left(1 \mathrm{mmol}^{-1}\right)$, almost all oocytes $(98 \%)$ were penetrated, and $87 \%$ of penetrated oocytes were polyspermic (Funahashi et al., 2000). However, when IVF medium was supplemented with fertilization-promoting peptide (FPP; $100 \mathrm{nmol} \mathrm{I}^{-1}$ ) or adenosine $\left(10 \mu \mathrm{mol}^{-1}\right)$ a high penetration rate $(71-75 \%)$ was maintained with a significantly reduced frequency of polyspermy $(20-25 \%)$. Furthermore, analysis of the functional state of spermatozoa exposed to these compounds revealed that FPP and adenosine stimulated 
capacitation but inhibited spontaneous acrosome reaction. In contrast, caffeine stimulated both capacitation and acrosome reaction. Accordingly, it may be possible to minimize the problem of polyspermic penetration by replacing the caffeine with FPP or adenosine.

The type of IVF medium may also affect the incidence of polyspermy (A. Kidson, personal communication). This worker examined fertilization parameters using either modified Tyrode's albumin lactate pyruvate (mTALP) or modified Tris-buffered medium (mTBM) as IVF medium. At a low sperm concentration $\left(4 \times 10^{5}\right.$ spermatozoa $\left.\mathrm{ml}^{-1}\right)$, penetration (54 versus $32 \%$ ) and polyspermy (40 versus $10 \%$ ) were higher in mTALP than mTBM, respectively. A ten-fold higher sperm concentration increased penetration rates ( 82 versus $79 \%$ ) similarly for MTALP and $\mathrm{mTBM}$, respectively. Incidence of polyspermy was $76 \%$ for MTALP and $26 \%$ for $\mathrm{mTBM}$. Therefore, medium and sperm concentration interact to produce different rates of polyspermy.

\section{Developmental competence of pig embryos}

Early attempts to culture in vivo-derived one-cell pig embryos in various culture media were consistently met with a developmental arrest at the four-cell stage (Davis, 1985). However, when collected at the four-cell stage and placed in culture, embryos continued development to the blastocyst stage. Numerous approaches have been used to circumvent the in vitro developmental block by using oviduct organ culture, co-culture with oviductal cells and oviductal fluid supplementation (see Day et al., 2000a). In more recent studies, $>70 \%$ of in vivo-derived embryos developed to the blastocyst stage in modified Whitten's medium (mWM; Beckmann and Day, 1993), North Carolina State University 23 medium (NCSU 23; Petters and Wells, 1993), lowa State University medium (ISU; Youngs et al., 1993) and Beltsville embryo culture medium 3 (BECM-3; Dobrinsky et al., 1996).

Type of culture medium and embryo development. Although various culture media have proven to be equally competent to support development of in vivo-derived embryos to the blastocyst stage, various degrees of success have been observed with in vitro-produced embryos, thus indicating the different sensitivity of these embryos to the type of culture medium. Abeydeera et al. (1999) compared the developmental ability of in vitro-matured and fertilized embryos in four different culture media. Highest $(30 \%)$ and lowest $(5 \%)$ proportions of blastocyst development were observed in NCSU and $\mathrm{mWM}$, respectively, with the other two media (ISU and BECM) producing intermediate rates of blastocyst formation. One difference between NCSU and $\mathrm{MWM}$ is the presence of a higher sodium lactate concentration (25 mmol $~^{-1}$ ) in mWM. Supplementation of NCSU with 25 mmol sodium lactate $\left.\right|^{-1}$ significantly decreased blastocyst development ( 14 versus $32 \%$ ). A similar lactate concentration has been found to be inhibitory to development of early stage pig embryos (Davis, 1985). However, reducing the lactate concentration in $\mathrm{mWM}$ did not improve blastocyst development. Blastocyst development in ISU (14\%) was higher than in mWM (5\%). Differences between these two media are the presence of low lactate concentrations $\left(12.9 \mathrm{mmol}^{-1}\right)$ and absence of glucose in ISU medium. These results indicate that the presence of a higher concentration of lactate or glucose in mWM may be detrimental to the development of in vitro-matured and fertilized embryos. Indeed, culture of embryos in NCSU lacking glucose but supplemented with low concentrations of lactate $\left(4.5 \mathrm{mmol}^{-1}\right)$ and pyruvate $\left(0.33 \mathrm{mmol}^{-1}\right)$ for the first $72 \mathrm{~h}$ followed by NCSU with glucose for $72 \mathrm{~h}$ improved blastocyst development (L. R. Abeydeera, unpublished). It is concluded that NCSU appears to be the most suitable medium available for in vitro production of pig blastocysts, whereas other media are effective for culture of in vivo-derived embryos. 
Table 7. Improvement in pig blastocyst development with modifications to the oocyte maturation medium

\begin{tabular}{|c|c|c|c|}
\hline Maturation medium & Modification & Blastocysts (\%) & Reference \\
\hline NCSU $23+10 \% p F F$ & $\begin{array}{l}\text { Control } \\
\text { Preincubation in IVM } \\
\text { medium for } 12 \mathrm{~h} \text { before } \\
\text { addition of hormones }\end{array}$ & $\begin{array}{r}9^{\mathrm{a}} \\
23^{\mathrm{b}}\end{array}$ & Funahashi et al., 1997a \\
\hline NCSU $37+10 \%$ pFF & $\begin{array}{l}\text { Control } \ddot{~} \\
\text { CAMP for } 20 \mathrm{~h}\end{array}$ & $\begin{array}{l}9^{\mathrm{a}} \\
22^{\mathrm{b}}\end{array}$ & Fünahashi ef al., 1997b \\
\hline NCSU $2 \dot{3}+10 \% \mathrm{pFF}$ & $\begin{array}{l}\text { Control } \\
\text { Follicular shell pieces }\end{array}$ & $\begin{array}{l}18^{\mathrm{a}} \\
36^{\mathrm{b}}\end{array}$ & Abeydeera et al., 1998a \\
\hline TCM-199+25\% pFF & $\begin{array}{l}\text { Control } \\
500 \mu \mathrm{mol} \text { cysteamine }\left.\right|^{-1}\end{array}$ & $\begin{array}{r}1^{\mathrm{a}} \\
12^{\mathrm{b}}\end{array}$ & Grupen et al., 1995 \\
\hline NSCU $23+10 \% p F F$ & $\begin{array}{l}\text { Control } \\
12.5 \mu \mathrm{mol} \mathrm{BME} \mathrm{I-1} \\
25 \mu \mathrm{mol} \mathrm{BME} \mathrm{I}^{-1}\end{array}$ & $\begin{array}{l}26^{\mathrm{a}} \\
34^{\mathrm{b}} \\
41^{\mathrm{b}}\end{array}$ & Abeydeera et al., 1998b \\
\hline NCSU $23+10 \%$ pFF & $\begin{array}{l}\text { Control } \\
1 \mathrm{ng} \mathrm{EGF} \mathrm{ml} \mathrm{l}^{-1} \\
10 \mathrm{ng} \mathrm{EGF} \mathrm{ml}^{-1}\end{array}$ & $\begin{array}{l}21^{a} \\
33^{b} \\
42^{b}\end{array}$ & Abeydeera et al., 1998c \\
\hline TCM $-199+0.1 \%$ PVA & $\begin{array}{l}\text { Control } \\
10 \mathrm{ng} \mathrm{EGF} \mathrm{m}^{-1}\end{array}$ & $\begin{array}{l}22^{\mathrm{a}} \\
37^{\mathrm{b}}\end{array}$ & Abeydeera et al., 2000 \\
\hline
\end{tabular}

NCSU: North Carolina State University; pFF: pig follicular fluid; IVM: in vitro maturation; TCM-199: tissue culture medium 199; BME: $\beta$-mercaptocthanol; EGF: epidermal growth factor; PVA: polyvinylalcohol.

abWithin a study, different superscripts indicate significani differences $(P \leqslant 0.05)$.

Embryo development with modifications to IVM medium. Production of blastocysts through IVM-IVF techniques has resulted in variable success. Many of the failures can be attributed to poor cytoplasmic maturation or a high incidence of polyspermy or both. However, improvements in embryo development to the blastocyst stage have been achieved by introducing various modifications to the IVM system (Table 7). Many of the effective modifications increased the. intracellular glutathione concentration in oocytes and can be related to their developmental competence. After sperm penetration, some of the glutathione is used for sperm nuclear decondensation and oocytes with a higher glutathione content may retain more glutathione than do those with a low glutathione contents. Day et al. (2000a) suggested that intracellular glutathione could eliminate the oxidative damage caused by reactive oxygen species generated during culture in a conventional $5 \% \mathrm{CO}_{2}$ in air environment, which is detrimental to. embryo development. Therefore, intracellular glutathione content of pig oocytes after IVM could be a potential biochemical marker to determine the effectiveness of an IVM system and subsequent developmental competence of oocytes.

Embryo development with modifications to IVF system. A significant improvement in blastocyst development has been observed when glutathione was supplemented during IVF in pigs (Boquest et al., 1999). The higher blastocyst yields did not appear to be related to an 
increase in glutathione concentrations in putative zygotes. Although the mechanism is not known, it is possible that extracellular glutathione may have effects on spermatozoa or oocytes or both. It was suggested that any detrimental effects on spermatozoa and oocytes by reactive oxygen species generated during IVF might have been counteracted by the presence of glutathione to ensure normal embryo development.

In a recent study, a higher rate of penetration ( 80 versus $57 \%$ ) and blastocyst development ( 30 versus $8 \%$ ) was observed when spermatozoa and oocytes were co-incubated in IVF medium for $10 \mathrm{~min}$ followed by transfer of oocytes with zona-bound spermatozoa to a fresh IVF medium for $5 \mathrm{~h}$ (Grupen and Nottle, 2000). It is surprising that this IVF strategy gave a higher penetration rate than controls. Intuitively, presence of spermatozoa for the entire coincubation period would be expected to result in a similar or a higher penetration rate than the 10 min sperm-oocyte co-incubation method. Nevertheless, such an IVF strategy could reduce the detrimental effects caused by reactive oxygen species that may otherwise occur when spermatozoa and oocytes are left together for longer co-incubation periods. It would be worthwhile to re-examine and use such IVF techniques to produce pig embryos in vitro.

Embryo development with hyaluronic acid. An improvement in blastocyst development ( 70 versus $45 \%$ ) was observed when in vivo-derived one- to two-cell stage pig embryos were cultured in the presence of hyaluronic acid (Miyano et al., 1994). This stimulatory effect was not observed when culture medium contained a higher concentration $(0.4$ versus $1.5 \% \mathrm{w} / \mathrm{v})$ of $\mathrm{BSA}$, indicating that a factor or factors in BSA may become toxic to embryos at higher concentrations. Similarly, Kano et al. (1998) observed the beneficial effects of hyaluronic acid on blastocyst development of in vitro-matured and fertilized pig embryos. Hyaluronic acid has been localized in tissues and intraluminal fluid of pig oviduct (Tienthai et al., 2001), which indicates a possible involvement during embryo development. Glycosaminoglycans promote the viability of pig oocytes (Sato et al., 1990). The exact mechanism of hyaluronic acid-improved embryo development is not known. However, the involvement of hyaluronic acid in sustaining embryo viability should be considered in future work.

\section{Embryo morphology and quality}

Although the success achieved in improving the production of blastocysts by in vitro techniques is notable, distinct morphological differences have been observed between in vitro- and in vivo-produced embryos, including blastocysts (Wang et al., 1999). Well-defined blastomeres in early stage embryos and a prominent inner cell mass in blastocysts are evident in embryos recovered in vivo. According to Papaioannou and Ebert (1988), the number of cells in in vitro-produced blastocysts is lower than in in vivo-produced blastocysts. It is possible that inadequate cytoplasmic maturation of in vitro-matured oocytes or suboptimal embryo culture conditions is responsible for the poor embryo quality. Transfer of in vitromatured and fertilized zygotes to the oviducts of recipient animals and then recovery by retrogate flushing 5 days later resulted in blastocysts with cell numbers several-fold higher (106-136 versus 10-21) than blastocysts developed in vitro (Funahashi et al., 1994b). In another study, the number of blastocyst cells after in vitro and in vivo development of in vivoderived one- to two-cell embryos was examined (Machaty et al., 1998). Compared with blastocysts developed in culture, a two-fold increase in cell number (25 versus 55 ) was observed for blastocysts developed in vivo. Collectively, the above findings indicate that suboptimal embryo culture conditions are likely to be the reason for low numbers of cells.

Recent evidence showed that partial inhibition of oxidative phosphorylation at the morula stage can significantly increase the proportion of blastocysts and their number of cells 
Table 8. Results of transfer of in vitro-produced pig embryos

\begin{tabular}{llcl}
\hline Source of spermatozoa & Embryonic stage & Piglets/recipients & Reference \\
\hline Fresh & Two- to four-cell & $9 / 1$ & Mattioli et al., 1989 \\
Fresh & Two-to four-cell & $19 / 3$ & Funahashi et al., 1997b \\
Frozen-thawed & Two- to four-cell & $18 / 5$ & Abeydeera et al., 1998a \\
Frozen-thawed & Two- to four-cell & $7 / 1$ & Abeydeera et al., 1998c \\
& Eight-cell to morula & $11 / 2$ & Kikuchi et al., 1999 \\
Frozen-thawed & One-cell & $17 / 3$ & Abeydeera et al., 2000 \\
Frozen-thawed & Eight-cell to morula & $82 / 12$ & \\
\hline
\end{tabular}

(Machaty et al., 2001). In the presence of inhibitors, it is assumed that the total ATP production by the embryo is low. A similar increase in blastocyst development and number of cells was also observed when morula stage embryos were cultured under low $(5 \%)$ oxygen tension (Machaty et al., 2001). In a previous study, no improvement in blastocyst development was observed when zygotes were cultured at a low oxygen tension for the entire culture period (Machaty et al., 1998). The above findings indicate that ATP production in embryos after compaction may favour glycolysis over oxidative phosphorylation. In turn, it may be important to establish a sequential culture environment, $20 \%$ oxygen up to the morula stage and $5 \%$ oxygen for later stages, to reduce ATP production and generate better quality pig embryos in vitro.

\section{Embryo transfer}

Production of pig litters through embryo transfer techniques using in vitro-matured and fertilized embryos would eliminate the necessity of in vivo-derived embryos. Although initial embryo development can be achieved in culture, the ultimate test of their viability is to establish pregnancies and live births after transfer to recipient animals. Various degrees of success in pregnancies and live births have been achieved after transfer of in vitro-matured and fertilized embryos to the oviduct or uterus of recipient gilts (Table 8). A potential problem is asynchrony between the embryo and oviduct or uterus. Routine transfers with in vitroproduced embryos are performed to a recipient at least $24 \mathrm{~h}$ behind the embryonic age and accurate detection of oestrus is a critical factor. In addition, $>30$ embryos are deposited in the oviduct or uterus at transfer. There is little information available about the ability of in vitroproduced embryos to hatch in vivo. Under in vitro conditions, $<10 \%$ of blastocysts hatch in NCSU 23 medium containing BSA (L. R. Abeydeera, unpublished). However, addition of $5-10 \%$ FCS at about days $4.5-5.0$ of culture can increase hatching to $30-40 \%$. Problems associated with in vivo hatching of in vitro-produced embryos could negatively affect the litter size. Therefore, development of embryo culture systems that stimulate hatching would probably improve pregnancy rate and litter size.

\section{Fate of polyspermic oocytes}

Polyspermic fertilization in mammals is considered pathological and usually results in early death of the zygote (Hunter, 1991). Recent studies indicate that polypronuclear oocytes produced from IVM-IVF cleave and develop to the blastocyst stage in vitro or in vivo at a rate similar to that of two-pronuclear oocytes (Han et al., 1999a). However, they have fewer inner cell mass nuclei compared with blastocysts derived from oocytes with two pronuclei. It 
should be noted that polypronuclear oocytes used in the study of Han et al. (1999a) contained one female pronucleus and two male pronuclei. In contrast to blastocysts derived from twopronuclear oocytes, some blastocysts developed from polypronuclear oocytes showed abnormal ploidy, including haploids, triploids and tetraploids. Interestingly, transfer of polypronuclear oocytes to recipients resulted in pregnancies (Han et al., 1999b). At day 40 of pregnancy, 16 fetuses were recovered from three recipients that received polyspermic oocytes. Analysis of ploidy in eight fetuses revealed one triploid, one mosaic (diploid and tetraploid) and the remainder had diploid cells. When four pregnant recipients were allowed to continue beyond day 40 , one recipient showed oestrus at day 60 and one on day 97 . The remaining animals farrowed five live piglets with a normal ploidy. It seems that some of the polypronuclear pig oocytes possess an as yet unknown mechanism to prevent or correct their ploidy. The location of pronuclei within the cytoplasm of polypronuclear oocytes appears to have a significant effect on determining the ploidy of the resulting embryo before the first cell division (Han et al., 1999b).

\section{Conclusion}

It is now possible to produce viable pig embryos through in vitro techniques. Supplementation with cysteine during oocyte maturation can alleviate the problem of poor male pronuclear formation. It may also be possible to reduce polyspermy, at least in part, by changing the $\mathrm{NaCl}$ concentration of culture medium. Consideration should also be given to exposure of oocytes to oviductal cells and their secretory products before or during sperm-oocyte interaction to reduce polyspermy. It may be necessary to replace caffeine with adenosine to stimulate sperm capacitation and realise normal penetration. A sequential embryo culture environment may improve the quality of blastocysts. It is envisaged that combinations of these improved systems will yield a higher proportion of viable blastocysts capable of establishing successful pregnancies and eventually reduce the number of embryos necessary per transfer. In vitro production of pig embryos, in conjunction with improvements in non-surgical embryo transfer techniques, has tremendous potential for basic research and commercial applications.

The author is very grateful to B. N. Day, D. L. Davis and J. E. Anderson for critical reading and editing of the manuscript.

\section{References}

Abeydeera LR and Day BN (1997a) In vitro penetration of pig oocytes in a modified Tris-buffered medium: effect of BSA, calfeine and calcium Theriogenology 48 537-544

Abeydeera LR and Day BN (1997b) Fertilization and subsequent development in vitro of pig oocytes inseminated in a modified Tris-buffered medium with frozen-thawed ejaculated spermatozoa Biology of Reproduction 57 729-734

Abeydeera LR, Funahashi $H, K i m$ NH and Day BN (1997) Chlotetracycline fluorescence patterns and in vitro fertilization of frozen-thawed boar spermatozoa incubated under various bicarbonate concentrations Zygote 5 117-125

Abeydeera LR, Wang WH, Cantley TC, Rieke A and Day BN (1998a) Coculture with follicular shell pieces can enhance the developmental competence of pig oocytes after in vitro fertilization: relevance to intracellular glutathione Biology of Reproduction 58 213-218
Abeydeera LR, Wang WH, Cantley TC, Prather RS and Day BN (1998b) Presence of $\beta$-mercaptoethanol can increase the glutathione content of pig oocytes matured in vitro and the rate of blastocyst development after in vitro fertilization Theriogenology 50 747-756

Abeydeera LR, Wang WH, Cantley TC, Rieke A, Prather RS and Day BN (1998c) Presence of epidermal growth factor during in vitro maturation of pig oocytes and embryo culture can modulate blastocyst development after in vitro fertilization Molecular Reproduction and Development 51 395-401

Abeydeera LR, Prather RS and Day BN (1999) Developmental ability of in vitro-derived pig embryos in four different culture media Biology of Reproduction (Supplement) 60128 (Abstract)

Abeydeera LR, Wang WH, Cantley TC, Rieke A, Murphy CN, Prather RS and Day BN (2000) Development and viability of pig oocytes matured in a protein-free medium 
containing epidermal growth factor Theriogenology 54 787-797

Beckmann LS and Day BN (1993) Effects of media $\mathrm{NaCl}$ concentration and osmolarity on the culture of earlystage porcine embryos and the viability of embryos cultured in a selected superior medium Theriogenology $39611-622$

Boquest AC, Abeydeera LR, Wang WH and Day BN (1999) Effect of adding reduced glutathione during insemination on the development of porcine embryos in vitro. Theriogenology 51 1311-1319

Buhi WC, $O^{\prime B}$ rien B, Alvarez $1 M$, Erdos G and Dubois D (1993) Immunogold localization of porcine oviductal secretory proteins within the zona pellucida, perivitelline space, and plasma membrane of oviductal and uterine oocytes and early embryos Biology of Reproduction 48 1274-1283

Buhi WC, Alvarez IM and Kouba Al (2000) Secreted proteins of the oviduct Cells, Tissues, Organs 166 165-179

Bureau M, Bailey JL and Sirard MA (2000) Influence of oviduct cells and conditioned media on porcine gametes Zygote 8 139-144

Cordova A, Ducolomb Y, Jimenez I, Casas E, Bonilla E and Betancourt $M$ (1997) In vitro fertilizing capacity of frozen-thawed boar semen Theriogenology 47 1309-1317

Davis DL (1985) Culture and storage of pig embryos Journal of Reproduction and Fertility Supplement 33 115-124

Day BN, Abeydeera LR and Prather RS (2000a) Recent progress in pig embryo production through in vitro maturation and fertilization techniques. In Boar Semen Preservation N pp 81-92 Eds LA Johnson and HD Guthrie. Allen Press Inc., Kansas

Day BN, Abeydeera LR, Cantley TC, Rieke A and Murphy CN (2000b) Exposure of pig oocytes to estrus oviduct can influence the morphological, physical and in vitro fertilization parameters Theriogenology 53418 (Abstract)

Dobrinsky JR, Johnson LA and Rath D (1996) Development of a culture medium (BECM-3) for porcine embryos: effects of bovine serum albumin and fetal bovine serum on embryo development Biology of Reproduction 55 1069-1074

Flesch FM and Gadella BM (2000) Dynamics of the mammalian sperm plasma membrane in the process of fertilization Biochimica et Biophysica Acta 1469 197-235

Fraser LR (1995) Ionic control of sperm function Reproduction, Fertility and Development 7 905-925

Funahashi $H$ and Day BN (1993) Effects of follicular fluid at fertilization in vitro on sperm penetration in pig oocytes Journal of Reproduction and Fertility 99 97-103

Funahashi $\mathbf{H}$ and Day BN (1997) Advances in in vitro production of pig embryos Journal of Reproduction and Fertility Supplement 52 271-283

Funahashi H, Cantley TC, Stumpf TT, Terlouw SL and Day BN (1994a) Use of low-salt culture medium for in vitro maturation of porcine oocytes is associated with elevated oocyte glutathione levels and enhanced male pronuclear formation after in vitro fertilization Biology of Reproduction 51 633-639
Funahashi H, Stumpf TT, Terlouw SL, Cantley TC, Rieke A and Day BN (1994b) Developmental ability of porcine oocytes matured and fertilized in vitro. Theriogenology 41 1425-1433

Funahashi H, Cantley TC and Day BN (1997a) Preincubation of cumulus-oocyte complexes before exposure to gonadotropins improves the developmental competence of porcine embryos matured and fertilized in vitro. Theriogenology $47679-686$

Funahashi H, Cantley TC and Day BN (1997b) Synchronization of meiosis in porcine oocytes by exposure to dibutyryl cyclic AMP improves developmental competence following in vitro fertilization Biology of Reproduction 57 49-53

Funahashi H, Fujiwara T and Nagai $\mathbf{T}$ (2000) Modulation of the function of boar spermatozoa via adenosine and fertilization promoting peptide receptors reduces the incidence of polyspermic penetration into porcine oocytes Biology of Reproduction 63 1157-1163

Grupen CG and Notıle MB (2000) A simple modification of the in vitro fertilization procedure improves the efficiency of in vitro pig embryo production Theriogenology 53 422 (Abstract)

Grupen CG, Nagashima $H$ and Nottle MB (1995) Cysteamine enhances in vitro development of porcine oocytes matured and fertilized in vitro. Biology of Reproduction 53 173-178

Han YM, Abeydeera LR, Kim JH, Moon HB, Cabot RA, Day BN and Prather RS (1999a) Growth retardation of inner cell mass cells in polyspermic porcine embryos produced in vitro. Biology of Reproduction 601110-1113

Han YM, Wang WH, Abeydeera LR, Petersen AL, Kim JH, Murphy C, Day BN and Prather RS (1999b) Pronuclear location before the first cell division determines ploidy of polyspermic pig embryos Biology of Reproduction 61 1340-1346

Harrison RAP (1996) Capacitation mechanisms, and the role of capacitation as seen in eutherian mammals Reproduction, Fertility and Development 8 581-594

Hunter RHF (1991) Oviduct function in pigs, with particular reference to the pathological condition of polyspermy Molecular Reproduction and Development 29 385-391

Hunter RHF (1993) Sperm:egg ratios and putative molecular signals to modulate gamete interactions in polytocous mammals Molecular Reproduction and Development 35 324-327

Kano K, Miyano T and Kato S (1994) Effect of oviduct epithelial cells on fertilization of pig oocytes in vitro. Theriogenology 42 1061-1068

Kano K, Miyano $T$ and Kato $S$ (1998) Effects of glycosaminoglycans on the development of in vitromatured and -fertilized porcine oocytes to the blastocyst stage in vitro. Biology of Reproduction 58 1226-1232

Kikuchi K, Kaziwazaki N, Noguchi J, Shimada A, Takahashi $R$, Hirabayashi $M$, Shino $M$, Ueda $M$ and Kaneko $H$ (1999) Developmental competence, after transfer to recipients, of porcine oocytes matured, fertilized, and cultured in vitro. Biology of Reproduction 60 336-340

Kouba AJ, Abeydeera LR, Alvarez IM, Day BN and Buhi WC (2000) Effects of the porcine oviduct-specific glycoprotein on fertilization, polyspermy and embryonic 
development in vitro. Biology of Reproduction 63 242-250

Machaty Z, Day BN and Prather RS (1998) Development of early porcine embryos in vitro and in vivo. Biology of Reproduction 59 451-455

Machaty Z, Thompson JC, Abeydeera LR, Day BN and Prather RS (2001) Inhibitors of mitochondrial ATP production al the time of compaction improve development of in vitro produced porcine embryos Molecular Reproduction and Development 58 39-44

Mattioli M, Bacci ML, Caleati C and Seren E (1989) Developmental competence of pig oocytes matured and fertilized in vitro. Theriogenology 31 1201-1207

Miyano T, Hiro-oka RE, Kano K, Miyake $M$, Kusunoki $H$ and Kato $S$ (1994) Effecls of hyaluronic acid on the development of 1- and 2-cell porcine embryos to the blastocyst stage in vitro. Theriogenology 41 1299-1305

Nagai T and Moor RM (1990) Effect of oviduct cells on the incidence of polyspermy in pig eggs fertilized in vitro. Molecular Reproduction and Development 26 $377-382$

Nagai T, Niwa K and Iritani A (1984) Eífect of sperm concentration during preincubation in a defined medium on fertilization in vitro of pig follicular oocytes Journal of Reproduction and Fertility 70 271-275

Nagai T, Takahashi T, Masuda H, Shioya Y, Kuwayama M, Fukushima $M$, Iwasaki S and Hanada $A$ (1988) in-vitro fertilization of pig oocyles by frozen boar spermatozoa Journal of Reproduction and Fertility 84 585-591

Nagai T, Takenaka A, Mori T and Hirayama M (1994) Effects of caffeine and casein phosphopeptides on fertilization in vitro of pig oocytes matured in culture Molecular Reproduction and Development 37 452-456

Niwa K (1993) Effectiveness of in vitro maturation and in vitro fertilization techniques in pigs fournal of Reproduction and Fertility Supplement 48 49-59

Papaioannou VE and Ebert KM (1988) The preimplantation pig embryo: cell number and allocation to trophectoderm and inner cell mass of the blastocyst in vivo and in vitro. Development 102 793-803

Perreault SD, Barbee RR and Slott VI (1988) Importance of glutathione in the acquisition and maintenance of sperm nuclear decondensing activity in maturing hamster oocytes. Developmental Biology 125 181-186

Petters RM and Wells KD (1993) Culture of pig embryos Journal of Reproduction and Fertility Supplement $\mathbf{4 8}$ $61-73$

Rath D (1992) Experiments to improve in vitro fertilization techniques for in vivo-matured porcine oocytes Theriogenology 37 885-896

Romar R, Coy P, Matas C, Gadea J, Campos I, Selles E and Ruiz S (2000) in vitro fertilization of porcine oocytes pre-cultured in the presence of porcine oviductal epithelial cells Theriogenology 53431 (Abstract)

Sato E, Miyamoto $\mathbf{H}$ and Koide SS (1990) Glycosaminoglycans in porcine follicular f́luid promoting viability of oocytes in culture Molecular Reproduction and Development 26 391-397

Suzuki K, Ebihara M, Nagai T, Clarke NGE and Harrison RAP (1994a) Importance of bicarbonate/ $\mathrm{CO}_{2}$ for fertilization of pig oocytes in vitro, and synergism with caffeine Reproduction, Fertility and Development 6 221-227

Suzuki K, Mori T and Shimizu H (1994b) In vitro fertilization of porcine oocytes in chemically defined medium Theriogenology 42 1357-1368

Suzuki K, Eriksson B, Shimizu H, Nagai T and RodriguezMartinez $\mathbf{H}(2000)$ Effect of hyaluronan on monospermic penetration of porcine oocytes fertilized in vitro. Journal of Andrology 23 13-21

Tienthai P, Kjellen L, Pertoft $\mathbf{H}$ and Rodriguez-Martinez $\mathbf{H}$ (2001) Localisalion and quantitation of hyaluronan and sulphated glycosaminoglycans in the tissues and intraluminal fluid of the pig oviduct Reproduction, Fertility and Development 12 173-182

Vatzias $G$ and Hagen DR (1999) Eifects of porcine follicular fluid and oviduct-conditioned media on maturation and fertilization of porcine oocytes in vitro. Biology of Reproduction $6042-48$

Wang WH, Niwa K and Okuda K (1991) /n-vitro penetration of pig oocytes matured in culture by frozen-thawed ejaculated spermatozoa Journal of Reproduction and Fertility 93 491-496

Wang WH, Abeydeera LR, Fraser LR and Niwa K (1995) Functional analysis using chlortelracycline fluorescence and in vitro fertilization of frozen-thawed ejaculated boar spermatozoa incubated in a protein-free chemically defined medium journal of Reproduction and Fertility 104 305-313

Wang WH, Abeydeera LR, Prather RS and Day BN (1998) Morphologic comparison of ovulated and in vitromatured porcine oocytes, with particular reference to polyspermy after in vitro fertilization Molecular Reproduction and Development 49 308-316

Wang WH, Abeydeera LR, Man YM, Prather RS and Day BN (1999) Morphologic evaluation and aclin filament distribution in porcine embryos produced in vitro and in vivo. Biology of Reproduction 60 1020-1028

Xu X, Ding J, Seth PC, Harbison DS and Foxcroft GR (1996a) In vitro fertilization of in vitro matured pig oocytes: effects of boar and ejaculate fraction Theriogenology 45 745-755

$X u X$, Seth PC, Harbison DS, Cheung AP and Foxcroft GR (1996b) Semen dilution íor assessment of boar ejaculate quality in pig IVM and IVF systems Theriogenology 46 1325-1337

Yoshida $M$ (1987) In vitro fertilization of pig oocytes matured in vivo. Japanese fournal of Veterinary Science $49711-718$

Yoshida M, Ishigaki K and Pursel VG (1992) Effect of maluration media on male pronucleus formation in pig oocytes matured in vitro. Molecular Reproduction and Development 31 68-71

Yoshida $M$, Ishigaki K, Nagai T, Chikyu $M$ and Pursel VG (1993) Glutathione concentration during maturation and after fertilization in pig oocytes: relevance to the ability of oocytes to form male pronucleus Biology of Reproduction 49 89-94

Youngs CR, Ford SP, McCinnis LK and Anderson LH (1993) Investigations into the control of litter size in swine: I. Comparative studies on in vitro development of Meishan and Yorkshire preimplantation embryos journal of Animal Science 71 1561-1565 